\title{
Enlightened state versus millenarian vision: A comparison between two historical novels ${ }^{1}$
}

\author{
Zélia Roelofse-Campbell \\ Unisa Centre for Latin American Studies \\ University of South Africa \\ PRETORIA
}

\begin{abstract}
Enlightened state versus millenarian vision: A comparison between two historical novels

Two millenarian events, one in Brazil (Canudos Rebellion, 1897) and the other in South Africa (Bulhoek Massacre, 1921) have inspired two works of narrative fiction: Mario Vargas Llosa's The War of the End of the World (1981) and Mike Nicol's This Day and Age (1992). In both novels the events are presented from the perspectives of both the oppressed landless peasants and the oppressors, who were the ruling élites. In both instances, governments which purported to be models of enlightenment and modernity resorted to violence and repression in order to uphold their authority. Vargas Llosa's novel was written in the Latin American tradition where truth and fiction mingle indistinguishably while in the South African novel fictional elements override historical truth.
\end{abstract}

\section{Introduction}

This article treats two historical events, both inspired by the millenarian vision: one took place in Brazil almost one hundred years ago; the other happened in South Africa seventy-five years ago. The events are, respectively, the Rebellion of Canudos and the Bulhoek massacre. Both events led to the massacre of landless peasants by governments which were considered "enlightened" at the time. Each of these events inspired a work of fiction: the Rebellion of Canudos is the theme of Mario Vargas Llosa's The War of the End of the World (1984, originally published in Spanish in 1981) and the Bulhoek massacre is the subject of Mike Nicol's This Day and Age (1992).

In Latin America the merging of history and narrative fiction is a long-standing tradition. In Spanish America, specifically, fictional writing (including that which

1 Revised and cxpanded version of a paper delivered at a conference on Latin American Literature, Unisa, 14 October 1994. 
combined elements of history) fell under the ban of the Inquisition. Novels were prohibited in order to protect the "spiritual integrity of the newly converted Indians" (Franco, 1969:18).

However, this prohibition had the opposite effect: far from disappearing, fiction encroached on almost every field of writing, "contaminating history, religion, poetry, science, art, speeches, journalism and people's daily habits" (Vargas Llosa, 1987:110). The War of the End of the World is written in this tradition. The novel is permeated with elements of historical discourse: historical events, public figures, descriptions of the landscape, et cetera. But Vargas Llosa relied on his imagination to complement historical events. In The War of the End of the World global accuracy and general truth are more important than strict factual detail. Historical characters are interwoven with invented ones, the latter serving an important purpose in that they assist the reader to better understand the complex events of this period (Oviedo \& Vargas Llosa, 1980:85). Thus, following the tradition of the Spanish American novel, truth can be winnowed from fiction.

The same tradition does not exist in South Africa because novels were never outlawed in the same way. In the specific case of This Day and Age, Mike Nicol recreates the millenarian episode of Bulhoek, but in a totally fictional manner. Consequently, it is very difficult to reconcile historical fact with the narrative.

It is significant that the only comprehensive history of the Bulhoek massacre is by an American scholar - Robert R. Edgar, who wrote his Ph.D. thesis on the topic (see Edgar, 1979 and Edgar, 1988). Similarly, the Canudos rebellion gained a more objective approach by means of the historical novel by the Peruvian Mario Vargas Llosa.

\section{Historical background to the rebellion of Canudos}

The Canudos rebellion took place in the State of Bahia in North-East Brazil in 1897. Although Brazil had suffered from a number of regional revolts over the centuries, the country's history had been relatively stable and there had been nothing like Canudos before.

Canudos is located in the interior of Bahia, in the North-East, which was the poorest region of Brazil, subject to severe recurrent droughts. The central protagonist of the Canudos tragedy emerged in this region during the $1870 \mathrm{~s}-\mathrm{a}$ time of particularly severe drought. He was Antônio Vicente Mendes Maciel, known to posterity as Antônio Conselheiro (the Counsellor).

After a troubled early life Antonio Conselheiro travelled through the backlands of the North-East where, usually in the remotest of places, he restored churches 
and rebuilt cemetery walls. He was always helped by the local people. Before long, he began preaching and attracted a growing number of followers.

These followers were drawn from the landless or dispossessed peasantry. By an ironic twist the ranks of the dispossessed were swelled by former jagunços, these being the class of outlaws and hired guns of the great landowners. Many of these landowners were impoverished by a series of particularly severe droughts during the last decades of the nineteenth century and had to dismiss many of their jagunços (Da Cunha, 1966:200-201; see Facó, 1983).

In this environment of disaster and despair, many people were attracted to the informal ministry of Antônio Maciel, who became known as Bom Jesus Conselheiro (Blessed Jesus the Counsellor) (Queiroz, 1977:228).

At first supportive of Conselheiro, the Catholic Church turned against him, denouncing his sermons as "inflammatory". The reason was rooted in politics. On 15 November 1889 Emperor Pedro II, loved and revered by the poor people of Brazil, was overthrown by the army and a republic was established by the military with the support of the intelligentsia.

These civilian and military intellectuals were thoroughly imbued with a positivist world view. Educated men, they saw themselves as enlightened and were convinced that they would bring civilization and progress to the entire population; provided, that is, that they could overcome the resistence of "reactionary" elements of the population. The new positivist élite immediately secularized the state. The church lost its right to register births, marriages and deaths. These policies horrified Conselheiro and his followers, who did not understand them. Nor did the new élite attempt to explain them. Conselheiro began to preach against the Republic in 1893 (Da Cunha, 1966:213).

That was also the year in which Conselheiro and his followers settled on the abandoned farm of Canudos. Here they created a thriving, peaceful community which grew to a population of about thirty thousand within four years (Nogueira, 1978:41). The overthrow of the monarchy and the secularization of the state were seen as harbingers of the end of the world. An apocalyptic vision took hold of Conselheiro and his followers. Canudos was the New Jerusalem, where the chosen would peacefully await the imminent Day of Judgement. As for the Republic, that was the Antichrist (Queiroz, 1977:226-227).

Unfortunately the republican authorities completely misinterpreted the Canudos phenomenon. They, and their associated intelligentsia (including the press) saw Canudos as a dangerous centre of political subversion, backed by the might of the British Empire! This perception was reinforced by the success of the desperate Canudos rebels, spearheaded by the jagunços, in fending off three military 
expeditions against them. Only the fourth expedition, mounted with 12000 troops, succeeded in defeating them - by which time Conselheiro was dead of natural causes. There was no formal surrender of Canudos. Instead, massacre followed the victory of the "enlightened" army.

It was not until the publication of Euclides da Cunha's classic Os Sertöes in 1902 (Da Cunha, 1966 - Rebellion in the Backlands [Da Cunha, 1944]) that the truth came out. From the standpoint of Conselheiro and his followers, however, even Da Cunha did not fully document the war. Instead, he vilified Conselheiro as a neurotic, suffering from a form of progressive psychosis, and a synthesis of all the imperfections of the underdeveloped, uncivilized backlands people (Da Cunha, $1966: 193,194)$.

\section{The War of the End of the World}

Eighty-four years after this tragic episode had taken place Peruvian writer Mario Vargas Llosa published his novel La guerra del fin del mundo (Vargas Llosa, 1981 - The War of the End of the World [Vargas Llosa, 1984]), which was based on the Rebellion of Canudos. It took a work of fiction to bring to the reader the reality of the Canudos war, and to vividly portray it from the point of view of the vanquished. In The War of the End of the World, history becomes story, as Vargas Llosa recreates the universe of Canudos in a way that succeeds in portraying the viewpoint of Conselheiro and the jagunços, as well as that of the government. Although many books have been written on the Canudos Rebellion, it was Vargas Llosa who first gave the Canudos rebels a voice.

In The War of the End of the World, history and fiction are merged to instill in the reader a sense that he or she is, for the first time, reading the "truth", a truth which is not apparent in official government and press reports. In this work of narrative fiction the author succeeds through a very clever interplay of historical and fictional characters in communicating to the reader the authentic texture of the events which really happened at Canudos.

The character of Conselheiro permeates every facet of The War of the End of the World, dominating the story and its protagonists. The Counsellor, as an ascetic and frugal pilgrim who wanders through the backlands in search of dilapidated churches and cemeteries in need of repair, is well documented in Os Sertðes (Da Cunha, 1966:203). But the narrator of The War of the End of the World makes a point of presenting Conselheiro from a great distance as an image diffracted through the perception of his followers; the followers become the focalizer, the vehicle through which the events surrounding the Counsellor are presented (see Rimmon-Kenan, 1983:72): 
But he neither ate nor drank until he had gone as far as the church or the town and seen, once more, a hundred times over, that it was dilapidated, its paint faded, its towers unfinished and its walls full of holes and its floors buckling and its altars worm-eaten (Vargas Llosa, 1984:3).

We soon become intensely aware of the pilgrim's sorrow and heartfelt compassion for the people of the sertão (backlands). His chief concern, however, is the state of their souls and their happiness in the hereafter (cf. Da Cunha, 1966:209).

While Da Cunha tries to "explain" why a phenomenon such as the Counsellor came to pass by referring to his early life, his psychological make-up and environmental considerations, Vargas Llosa makes no such attempt. As the implied author he wishes to distance himself from the positivism which permeated Da Cunha's writings.

The result is that in the reader's mind Conselheiro is increasingly identified with Christ (Vargas Llosa, 1984:182, 191; cf. Queiroz, 1977:228), which is in accordance with historical fact. Under threat from the second expedition, the jagunços decide that their first task is to protect Conselheiro at all costs. The divine element is further emphasized by the use of the focused perspective, as explained by Vargas Llosa himself:

I decided that some people and some events in the novel should be presented to the reader at a great distance, that it was important, for instance, that Conselheiro should be perceived by the reader as he had been perceived by his followers, not as a human, flesh-and-blood figure, but as a mythical figure, as a divine kind of presence. For that reason it was important for Conselheiro to be far away from the reader at all times. The narrator never approaches Conselheiro; he is always looking at him from the perspective of his followers and describing him as he is perceived and felt by people who believe him to be a kind of divine incarnation (Vargas Llosa, 1991:138).

The last moments of Conselheiro's life, as presented in the novel, reflect the extent of his followers' devotion. They refuse to accept his physical deterioration and interpret the trickle of water coming out of his body when it is afflicted by dysentery as a form of divine "gift". The excrement becomes the host as, urged by the overzealous disciple nicknamed Little Blessed One, the followers take communion:

'Is this how you wish your slave to take Communion, Father? Is this not dew to me?' All the women of the Sacred Choir also took Communion, in the same way (Vargas Llosa, 1984:510). 
In his characterization of Conselheiro, Mario Vargas Llosa uses the technique of valorization. According to Genette (1982:400), valorization consists in bestowing upon the hero or heroine a pre-eminence which he or she lacked in the hypotext (in this case, Os Sertzes by Euclides da Cunha). Valorization enlarges the character's merit or symbolic value. In some cases, valorization is akin to rehabilitation, as is the case with Conselheiro in The War of the End of the World. He is rehabilitated and given the status of a saint; his words are made coherent and meaningful, especially within the context of his time and environment. While Euclides da Cunha vilified Antônio Conselheiro in $O s$ Sertz̃es, Mario Vargas Llosa vindicates him through fiction.

\section{The revolt of the Israelites at Bulhoek}

Like Brazil, South Africa had its own millenarian episode, namely the revolt of the Israelites at Bulhoek. The origins of the Bulhoek massacre were similar to those of Canudos. Here too, landless peasants, members of the Mfengu tribe, gathered around a messianic leader who gave them hope. That leader was Enoch Mgijima.

Mgijima had had his first vision in 1907. In 1909 he met and was inspired by William Crowdy, the black American leader of the Church of God and All Saints. Just as the Catholic Church turned against Conselheiro, so the Church of God rejected Mgijima because of his prophecies about a coming great war. (Mgijima was proved right by the outbreak of the First World War - Edgar, 1988:11.)

In 1910 Halley's comet reappeared. Mgijima told his followers this was a sign of Jehovah's anger, that they should return to the old (i.e. Old Testament) religion and worship God in the way the Patriarchs had; hence their name of "Israelites". If they refused to obey, Jehovah would punish them severely (Roux, 1964:135136).

As with Canudos, there was a political dimension to Bulhoek: the 1913 Land Act. It was this Act which had deprived Mgijima's peasant supporters (and many others) of their land (Holtzhausen, 1992). The effects of this Act were exacerbated by further legislation in 1919, by which many African sharecroppers and other peasants with squatters' rights on white-owned land were deprived of their tenure (Ingham, 1986:68).

In 1920 Mgijima and his followers - some 3000 in all - settled on Ntabelanga (the Mountain of the Rising Sun) at Bulhoek, $40 \mathrm{~km}$ south of Queenstown, Cape Province. There they awaited the end of the world in compliance with what Mgijima claimed was an instruction from God himself (Cameron \& Spies, 1987:244; Edgar, 1988:12-15). Mgijima proclaimed that "when the Day of 
Judgement came, accompanied by blood, fire and destruction, the Israelites would be transported to heaven in wagons" (Andrew, 1922).

At that time South Africa's Prime Minister was Jan Christiaan Smuts, the epitome of the "enlightened" statesman. Smuts denied Mgijima's request for an audience on the grounds that he was too busy and instead sent members of the Native Affairs Commission to meet the Israelites (Ingham, 1986:125).

The Israelites refused repeated demands from the authorities that they withdraw from Ntabelanga. The government thus sent a force of 800 men comprising police and troops against the Israelites. In the ensuing clash 183 Israelites men, women and children - were killed, and more than 100 wounded. Another 150 were taken prisoner (Cameron \& Spies, 1987:244; Edgar, 1988:33). The massacre occurred on 24 May 1921 - Jan Smuts' 51st birthday.

The very next day Smuts left for Europe to participate in discussions about the League of Nations. Ironically, 16 years later, in a 1937 address to St. Andrews University in Scotland, Smuts proclaimed (Smuts, 1994 [1934]:66; my italics):

The denial of human rights must in the long run lead to a cataclysm. The machinery of democracy may call, and does call, for reform, and the methods of enabling the people to exercise in freedom their influence on government may have to be altered from those at present in vogue ... [T]o suppose that in the modern world you can dispense with freedom in human government, that you can govern without the consent of the governed, is to fly in the face of decent human nature as well as the facts of history, ... Freedom is the most ineradicable craving of human nature.

The gap between lofty rhetoric and grim reality is only too apparent. As with Canudos, ideology and intellectual preconceptions blinded the rulers; in Smuts's case the intellectual blinkers were provided by the legal positivism in his mind.

Like Canudos, Bulhoek was taken up in oral literature (Saule, 1991). Although the episode inspired the Xhosa poet S.E.K Mghayi, who died in 1945 (Saule, 1991), no work of fiction was written on the massacre until 1992, when Mike Nicol published his novel This Day and Age.

\section{This Day and Age}

In his novel Nicol bases the character of Enoch Mistas on Enoch Mgijima. The novel contains some superbly written narrative passages in which the struggle of the dispossessed against the arrogance of the high officials of the white government is clearly depicted. When Mistas's people ask Captain Trotter why they have to disperse, the explanation, rendered in free indirect discourse is: 
Because here are harboured vagrants, bandits, deserters, murderers, traitors and other undesirable elements considered a threat to the well-being of citizens and a danger to the state. Not to mention the avoidance of tax, incitement to civil disobedience or grand blasphemy (Nicol, 1992:243-244).

The consequences of resistance were considered to be "The total clearance of this place in terms of the Slums Act, the relocation of people according to the Orderly Settlement of Peoples Act, the repayment of back tax plus penalties ..., and an admission-of-guilt fine for constituting an illegal gathering" (Nicol, 1992:244).

However, the historical characters in This Day and Age do not emerge in the clear and historically purposeful way that those of Vargas Llosa do in The War of the End of the World. Consequently, although Nicol's novel succeeds in bringing to light this otherwise forgotten, shameful episode, one cannot say that it reveals the historical truth of Bulhoek in the same way that The War of the End of the World reveals the true events of Canudos. This is at least partly because Mike Nicol makes the mistake of indulging in caricature in order to ridicule certain characters. Mistas is even portrayed as a person who indulges himself to the point of perversion. In This Day and Age the character of Enoch Mistas is devalorized in relation to the real Enoch Mgijima. Devalorization, according to Genette (1982:404), is the opposite of valorization: someone who is taken seriously in a previous text will be denigrated or ridiculed in the hypertext (in this case This Day and Age). This reader would have welcomed a more historically accurate account of the Israelites, an account in which the spiritual outlook of the Israelites is revealed in the way that Vargas Llosa succeeded in conveying the inner world of the inhabitants of Canudos. However, one should bear in mind that Vargas Llosa's work rests upon 500 years of a particular literary tradition in Latin America, a tradition which depends on the merging of truth and fiction.

The above criticisms notwithstanding, This Day and Age contains some very powerful moments, particularly at the end of the novel, when the field marshal surveys the field after the massacre and, in order to blot out an "uncomfortable" event, gives the following orders to his "anxious captain" (Nicol, 1992:268):

Send a message that our mission is accomplished; and get the men to start digging a hole. I want no signs of carnage, I want just burnt-out ruins. I want historians to say the tabernacle caught fire and the people of the prophet went out into the desert where they died. I want them to record such things in passing.

The narrator thus encapsulates the tragedy of "afterwards", denouncing the deeds of those in power. After the field marshal's orders are carried out to the letter, an inventory is taken, and 
an absolute assurance made that never in the future, never at all, will some ploughing farmer, caught by a glimpse of white in his field, climb off his tractor to find teeth, a splinter of femur, praying hands, broken bones. Let him wonder about a cartridge case, even a shard of metal, let him wonder at the ruins when he returns from planting pineapples, or the peacocks and the dragonflies that never leave the island, but let him never hold in his hands the small rifle-smashed skull of a child (Nicol, 1992:268).

\section{Conclusion}

Both episodes discussed in this article are tragic examples of misunderstanding and violence. Both came about because a group of poverty-stricken, dispossessed people were inspired by the millenarian vision as presented to them by two charismatic leaders. In both instances a state which regarded itself as enlightened misinterpreted the actions and beliefs of the poor. Both movements were seen as subversive of the "enlightened" order and ruthlessly crushed. In the case of Canudos, the memory of the tragedy did not fade over time, but the contemporary misconceptions were perpetuated by history. In contrast, Bulhoek was almost forgotten, even by history. With the approaching end of the second millennium, such episodes gain a new relevance, particularly in the case of both Brazil and South Africa, in their quest to gain a more just and equitable society.

Of the two works of fiction depicting the Canudos rebellion and the Bulhoek massacre, the novel The War of the End of the World by Mario Vargas Llosa definitely succeeds in contributing to our understanding of the historical truth of Canudos. Reading Vargas Llosa's work of narrative fiction one is left with a very clear understanding of the historical event of Canudos. The work of fiction has brought to light certain historical events which were, for a long time, considered "inconvenient", as they gave a voice to the oppressed, the dispossessed, the "other".

One cannot derive such understanding of the Bulhoek massacre from Nicol's work. To understand Bulhoek one must also read a historical account. Nevertheless, Mike Nicol's novel, This Day and Age, while not illuminating history in the same way, contributes towards our awareness of a forgotten episode in South African history and, as such, is a worthwhile endeavour. The very weakness of this novel must be the result of the system of apartheid. Because we have not known the other, we cannot write about him/her in the same compassionate way that Vargas Llosa could by writing in a tradition in which historical truth is revealed by narrative fiction.

\section{References}

Andrew, John 1992. The Warrior Who Survived at the Last Stand of the Israelites. Simday Times, 26 July. 
Cameron, T. \& Spies, S. B. (eds.) 1987. An Illustrated History of South Africa. Johannesburg : Jonathan Ball.

Da Cunha, E. 1944. Rebellion in the Backlands Translated by Samuel Putnam. Chicago : The University of Chicago Press.

Da Cunha, E. 1966 Os Seriões in Obra Completa ed por Afrânio Coutinho. Rio de Janeiro : José Aguilar Editora.

Edgar, Robert Russel. 1979. The Fifth Seal: Enoch Mgijima, the Israelites and the Bullhoek (sic) Massacre, 1921. Los Angeles : University of California. (Ph D. thesis.)

Edgar, Robert. 1988 Because They Chose the Plan of God. Johannesburg : Ravan Press

Facó, Rui 1983. Cangaceiros e Fanáticos. 7th edition. Rio de Janeiro : Editora Civilização Brasileira.

Franco, Jean 1969. An Introduction to Spanish-American Literature. Cambridge University Press.

Genette, Gérard. 1982. Palimpsestes. Paris : Seuil, "Poétique".

Holtzhausen, Evelyn. 1992. Evil Massacre is Resurrected Sunday Times, 26 July.

Ingham, Kenneth 1986. Jan Christian Smuts. The Conscience of South Africa. Johannesburg : Jonathan Ball

Nicol, Mike 1992. This Day and Age. Cape Town : David Philip

Nogueira, Ataliba. 1978. Amônio Conselheiro, Revisâo Histórica. A Obra Manuscrita de Antônio Conselheiro e que Pertenceu a Euclides da Cunha. São Paulo : Companhia Editôra Nacional.

Oviedo, J.M. \& Vargas Llosa, M 1980. Historia de la historia de la historia: conversación en Lima. Escandalar, 3(1):82-87.

Queiroz, Maria Isaura Pereira de. 1977. O Messianismo no Brasil e no Mundo. 2nd edition São Paulo : Edito̊ra Alfa-Omega.

Rimmon-Kenan, Shlomith. 1983. Narritive Fiction: Contemporary Poetics. London \& New York: Methuen.

Roux, Edward 1964. Time Longer than Rope. 2nd edition. Madison: The University of Wisconsin Press.

Saule, Ncedile 1991. Conversation with Zèlia Roelofse-Campbell. Pretoria : Unisa Centre for Latin American Studies, 23 July

Smuts, J.C 1994 (1934). Freedom: The inaugural address delivered at St. Andrews University on Oct. 17th, 193t London : Alexander Maclehose \& Company. In: The Loss of Innocence, edited by C. Vale \& I van den Ende Pretoria : HSRC Publishers p. 61-93.

Vargas Llosa, Mario 1981. La guerra del fin del mundo. 4th edition. Barcelona : Plaza y Janés.

Vargas Llosa, Mario 1984 The War of the Find of the World. London \& Boston : Faber \& Faber

Vargas Llosa, Mario 1987. Latin American Fiction and Reality. Times Literary Supplement:110-111, January 30

Vargas Llosa, Mario. 1991. A Writer's Reality. Syracuse, N Y. : Syracuse University Press 